\title{
Erratum: Phan, T.T.V., et al. Spontaneous Hinge-Bending Motions of Angiotensin I Converting Enzyme: Role in Activation and Inhibition. Molecules 2020, 25, 1288
}

\author{
Thi Tuong Vy Phan ${ }^{1}\left(\mathbb{D}\right.$, Seong-Yeong Heo ${ }^{2,3}$, Won-Kyo Jung ${ }^{2,3,4}$ and Myunggi Yi ${ }^{2,3, *(D)}$ \\ 1 Center for Advanced Chemistry, Institute of Research and Development, Duy Tan University, \\ 03 Quang Trung, Hai Chau, Danang 550000, Vietnam; phanttuongvy4@duytan.edu.vn \\ 2 Interdisciplinary Program of Biomedical, Electrical \& Mechanical Engineering, Pukyong National University, \\ Busan 48513, Korea; hsyads1@naver.com (S.-Y.H.); wkjung@pknu.ac.kr (W.-K.J.) \\ 3 Department of Biomedical Engineering, Pukyong National University, Busan 48513, Korea \\ 4 Marine Integrated Bionics Research Center, Pukyong National University, Busan 48513, Korea \\ * Correspondence: myunggi@pknu.ac.kr; Tel.: +82-51-629-5773
}

check for updates

Citation: Phan, T.T.V.; Heo, S.-Y.; Jung, W.-K.; Yi, M. Erratum: Phan, T.T.V., et al. Spontaneous

Hinge-Bending Motions of Angiotensin I Converting Enzyme: Role in Activation and Inhibition. Molecules 2020, 25, 1288. Molecules 2021, 26, 1508. https://doi.org/ $10.3390 /$ molecules 26061508

Received: 21 May 2020

Accepted: 2 December 2020

Published: 10 March 2021

Publisher's Note: MDPI stays neutral with regard to jurisdictional claims in published maps and institutional affiliations.

Copyright: (c) 2021 by the authors. Licensee MDPI, Basel, Switzerland. This article is an open access article distributed under the terms and conditions of the Creative Commons Attribution (CC BY) license (https:// creativecommons.org/licenses/by/ $4.0 /)$.
The authors wish to make the following corrections to the paper [1]: During the final preparation of the manuscript, the family name of the first author was omitted; also, the affiliation and the e-mail of the first author were not correctly input. We would thus like to make following changes to the paper [1], as follows:

\section{Thi Tuong Vy Phan ${ }^{1}$}

1 Center for Advanced Chemistry, Institute of Research and Development, Duy Tan University, 03 Quang Trung, Hai Chau, Danang 550000, Vietnam; phanttuongvy4@duytan.edu.vn

We apologize for this unintentional mistake, which, however, does not affect the results of this manuscript and the conclusions drawn from them.

\section{Reference}

1. Vy, T.T.; Heo, S.-Y.; Jung, W.-K.; Yi, M. Spontaneous Hinge-Bending Motions of Angiotensin I Converting Enzyme: Role in Activation and Inhibition. Molecules 2020, 25, 1288. [CrossRef] [PubMed] 